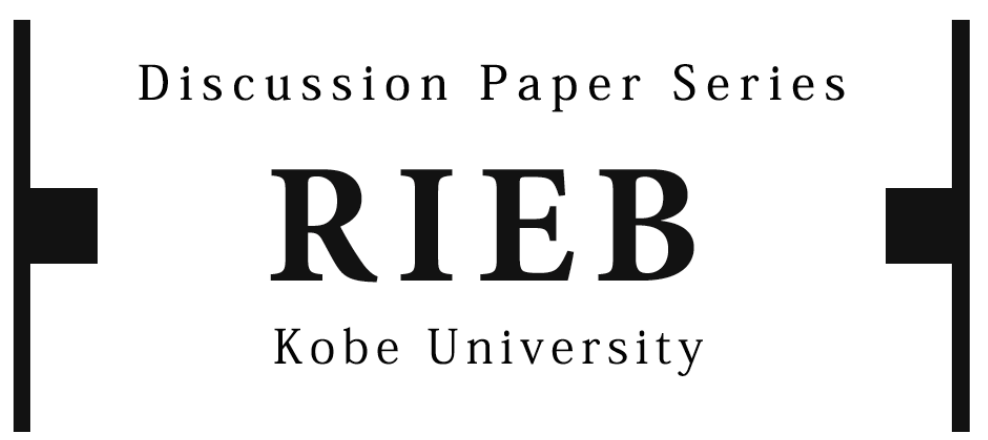

DP2012-13
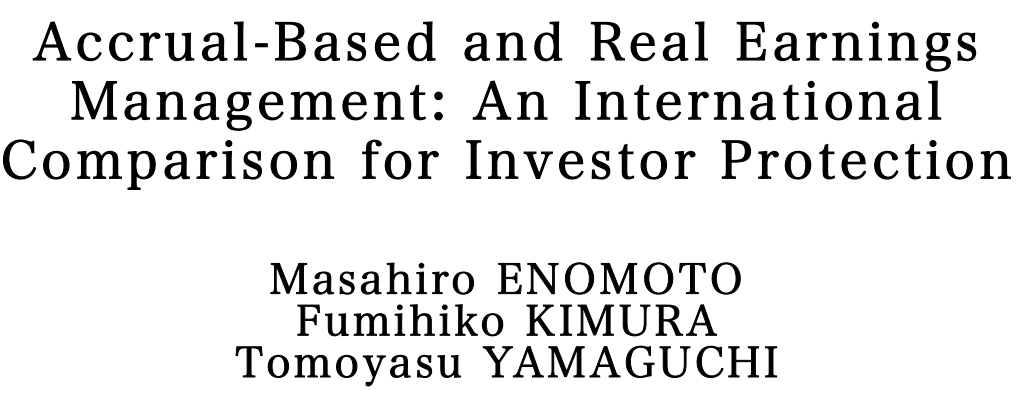

Revised May 11, 2015

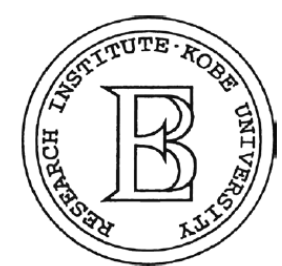

Research Institute for Economics and Business Administration Kobe University 


\title{
Accrual-based and Real Earnings Management: \\ An International Comparison for Investor Protection
}

\author{
Masahiro Enomoto* \\ Research Institute for Economics and Business Administration \\ Kobe University \\ 2-1 Rokkodaicho, Nada-ku, Kobe 657-8501, JAPAN \\ E-mail: menomoto@rieb.kobe-u.ac.jp \\ Phone: +81-78-803-7031; fax: +81-78-803-7031 \\ Fumihiko Kimura \\ Graduate School of Economics and Management \\ Tohoku University \\ 2-2-1 Katahira, Aoba-ku, Sendai 980-8577, JAPAN \\ E-mail: fkimura@econ.tohoku.ac.jp \\ Phone: +81-22-217-6282; fax: +81-22-217-6282
}

\section{Tomoyasu Yamaguchi}

Faculty of Business Administration

Tohoku Gakuin University

1-3-1 Tsuchitoi, Aoba-ku, Sendai 980-8511, JAPAN

E-mail: yamaguchi@mail.tohoku-gakuin.ac.jp

Phone: +81-22-721-3471; fax: +81-22-721-3471

May, 2015

* Corresponding author. 


\title{
Accrual-based and Real Earnings Management:
}

\section{An International Comparison for Investor Protection}

\begin{abstract}
This paper examines the differences in accrual-based and real earnings management across countries from the perspective of investor protection. Following prior research (Leuz et al., 2003), we hypothesize that accrual-based earnings management is more constrained by strict discipline in countries with stronger investor protection. For real earnings management in countries with stronger investor protection, we have two hypotheses. One is that real earnings management is more often implemented to substitute for accrual-based earnings management. The other is that real earnings management is less often implemented, as with accrual-based earnings management. Our examination uses data from 222,513 firm-year observations drawn from 38 countries covering 1991 to 2010. The results show that managers in countries with stronger investor protection tend to engage in real earnings management instead of accrual-based earnings management. We also find that real earnings management is constrained by analyst following. Our results are not affected by the control of audit quality or the calculation method used for earnings management measures according to country and year.
\end{abstract}

Highlights

- Earnings management is affected by investor protection in each country.

- Accrual-based earnings management decreases under stronger investor protection.

- Real earnings management increases under stronger investor protection.

- Real earnings management decreases with analyst following.

JEL Classification: G34 K22 M41 P4 G38

Keywords: earnings management, investor protection, corporation law, securities law, regulation 


\section{Introduction}

This paper examines the differences in accrual-based and real earnings management across 38 countries. Healy and Wahlen (1999, 368) state that earnings management occurs when managers use judgment in financial reporting and in structuring transactions to alter financial reports to either mislead some stakeholders about the underlying economic performance of the company or to influence contractual outcomes that depend on reported accounting numbers. Earnings management occurs through a change in the accrual process or a deviation from normal business activity, or both simultaneously; the former is called "accrual-based earnings management” (AEM) and the latter "real earnings management” (REM).

Earnings management is affected not only by the factors relating to each manager and firm but also by institutional factors such as laws, market mechanisms, and regulations (Wysocki, 2004). Institutional factors vary across countries. International comparative studies on earnings management have been very important and fruitful (Wysocki, 2011; Gordon et al., 2013). International comparative studies on earnings management have concentrated on AEM. Leuz et al. (2003) consider investor protection as an institutional factor influencing managerial behavior and investigate whether investor protection in various countries was related to AEM. ${ }^{1}$ They examine the relationship between outside investor protection and earnings management in 31 countries from 1990 to 1999, finding that AEM decreases in countries with stronger investor protection.

Boonlert-U-Thai et al. (2006) also investigate the relationship between investor protection and earnings management using data from 31 countries covering 1996 to 2002, suggesting that earnings were smoothed in countries where investor protection was advanced. Shen and Chih (2005) show that

\footnotetext{
${ }^{1}$ Investor protection is the power to prevent managers from expropriating minority shareholders and creditors within the constraints imposed by law (La Porta et al., 2002; Leuz et al., 2003).
} 
earnings management declines in countries with stronger investor protection and more transparent accounting disclosure for banks in 48 countries from 1993 to 1999.

Most of the research uses accrual-based measures as key proxies of earnings management. Besides accrual processes, managers can also change real activities to manage earnings. Recent studies have examined REM as an important topic in research on earnings management (e.g., Roychowdhury, 2006). While REM could have a negative impact on firms' future value (e.g., Bhojraj et al., 2009; Cohen and Zarowin, 2010), neither regulators nor auditors can restrain firms from engaging in REM. ${ }^{2}$ Scrutiny by regulators and auditors is weaker for REM than for AEM; thus, the costs of REM are lower (Francis et al., 2011).

Managers might choose cost-effective methods based on the features of AEM and REM; studies have analyzed the substitutability of the two types of earnings management. For example, Cohen and Zarowin (2010) and Zang (2012) present evidence on the tradeoffs between AEM and REM in U.S. firms. Zang (2012) finds tradeoffs between AEM and REM by focusing on their constraints. The results of their studies as well as those in Leuz et al. (2003) raise the questions of whether investor protection has an effect on REM in the international setting and whether substitution occurs between AEM and REM. In line with the focus on tradeoffs in REM research, we hypothesize that the level of investor protection in each country lead to such tradeoffs. Investor protection has developed globally, but national development levels vary; for example, the Sarbanes-Oxley Act is specific to the United States. Consequently, we can analyze the substitutability of the two types of earnings management at the international level. We predict that REM, rather than AEM, will be implemented in countries with stronger investor protection.

Managers might implement REM in order to bring earnings to a target level and conceal "true” firm performance and behavior, similar to the use of AEM. Additionally, REM could have a negative impact on a firm's future value and be undesirable for investors. For example, Cohen and Zarowin

\footnotetext{
2 Guuny (2010) suggests that REM makes a positive impact on the future value of firms.
} 
(2010) find that firms issuing seasoned equity offerings (SEO) engage in REM and that the decline in post-SEO performance due to REM is more severe than that caused by AEM. Kim and Sohn (2013) suggest that REM is positively associated with the implied cost of equity even after controlling for the effects of AEM. Thus, managers in countries with stronger investor protection might avoid REM as well as AEM. In this scenario, REM is less prevalent in countries with stronger investor protection.

Following Leuz et al. (2003), we measure AEM using three proxies: (1) the ratio of the standard deviation of operating income to that of operating cash flow, calculated with time-series data from each firm; (2) the correlation between changes in accruals and changes in operating cash flow computed from the pooled data in each country; and (3) the ratio of the absolute value of accruals to that of operating cash flow calculated in each firm-year. We measure REM employing two proxies: (1) the correlation between changes in sales and production costs and (2) the correlation between changes in sales and discretionary expenses. ${ }^{3}$

As investor protection variables, we use the strength of legal enforcement and the extent of outside investor rights under corporate and security law (La Porta et al., 1998, 2006). Furthermore, we treat disclosure regulations and the analyst's role as important investor protection factors, including the disclosure index and analyst following.

Our examination employs 222,513 firm-year observations from 38 countries covering 1991 to 2010. The results show that managers in countries with stronger outside investor rights tend to engage in REM instead of AEM and that REM is constrained by analyst following. This result is not affected by the control of audit quality or the calculation of earnings management measures according to country and year.

This paper offers two main contributions. First, most international comparative studies on earnings management (e.g., Leuz et al., 2003; Shen and Chih, 2005; Boonlert-U-Thai et al., 2006) have looked only at AEM. We also investigate REM based on the theoretical relationship between REM and

\footnotetext{
3 The correlation between the changes in sales and cash flows from operations, employed in Roychowdury (2006), is not included for the reason given in footnote 6 .
} 
AEM, finding a substitution effect between them regarding outside investor rights at the country level. However, the results also indicate that analyst following restricts REM. Taken together, the findings suggest that managers tend to apply REM where the legal environment constrains AEM and that the development of security markets increases the monitoring of managerial discretionary behaviors. Second, our results are much more reliable than those of previous studies because of our larger sample size and longer-term investigation.

The rest of this paper is organized as follows. Section 2 discusses AEM and REM and provides some institutional background. Section 3 shows our sample selection procedures and the measures of earnings management and investor protection. Section 4 presents the results on the relationship between earnings management and investor protection. Section 5 discusses some additional analyses, and Section 6 concludes the paper.

\section{Accrual-based and real earnings management and the institutional background}

Managers can opportunistically manage earnings by changing the accrual process because managers' various estimations and judgments are included in the process when they prepare financial statements. Thus, managers can implement AEM after the end of the fiscal year. However, AEM is more visible than REM due to the scrutiny of auditors and regulators, among others (Francis et al., 2011) and may lead to reversal in future periods.

In addition to the accrual process, managers can also manage earnings by changing the timing or structure of operating, investing, or financial decisions, known as REM. This can be more costly in terms of future cash flow, as it often cuts funding for research and development (R\&D) and marketing, increases price discounts, and reduces capital investments (Graham et al., 2005; Chen et al., 2010). However, stakeholders have more difficulty detecting REM than AEM, as REM is easier to camouflage as normal activity (Kothari et al., 2012). Thus, managers will choose AEM and/or REM depending on the economic context. We focus on both AEM and REM. 
Regulatory authorities impose various restrictions on managers carrying out AEM because earnings management can reduce outside investors' profits. The degree of restriction is believed to vary with the institutional factors of each country. Many studies attach importance to investor protection and include corporate law, accounting standards, and security markets as institutional factors. La Porta et al. $(1997,1998)$ show that each country's investor protection is based on its legal origin and that countries with stronger investor protection have larger and more open capital markets. Leuz et al. (2003) suggest that AEM decreases in countries with stronger investor protection. In a similar vein, disclosure systems and analyst following are components of investor protection, thereby reducing AEM (Yu, 2008; Degeorge et al., 2013). This leads to our first hypothesis:

H1. Ceteris paribus, accrual-based earnings management is more constrained in countries with stronger investor protection.

Though AEM is constrained, the motives for earnings management are not necessarily controlled. Moreover, investors in countries with developed capital markets should be cautious about earnings information. Therefore, managers in countries with stronger investor protection will tend to choose REM over AEM. The research supports this prediction. In a survey of chief financial officers, Graham et al. (2005) show that managers opt for REM because they fear the risks created by overzealous regulators. Analyzing mathematical models, Ewert and Wagenhofer (2005) also suggest that tighter accounting standards lead managers to prefer REM. Cohen et al. (2008) imply that U.S. managers switched from AEM to REM after the passage of the Sarbanes-Oxley Act, which was seen as strengthening investor protection. Thus, managers under stricter regulation tend to avoid AEM and implement REM to achieve income targets. In other words, the tightening of regulations leads to restrained AEM but tends to induce REM.

However, we should also consider another scenario. Investors might consider both AEM and REM to be undesirable, since REM can distort earnings and negatively affect a firm's future performance (Cohen and Zarowin, 2010). Similarly, Kim and Sohn (2013) find that the cost of capital 
relates positively to REM. Leuz et al. (2003, 506), focus on AEM, arguing that "strong and well enforced outsider rights limit insiders' acquisition of private control benefits, and consequently, mitigate insiders' incentives to manage accounting earnings because they have little to conceal from outsiders.” Their discussion may be considered to be unassociated with earnings management methods (i.e., either AEM or REM). Thus, managers in countries with stronger investor protection facing the threat of discipline might be restrained from engaging in both REM and AEM. Based on these competing arguments, we propose the following hypothesis (stated in null form):

H2. There is no association between real earnings management and the strength of investor protection in a country.

\section{Research design}

This study tests hypotheses on the relationship between both types of earnings management and investor protection. The subsections below present a detailed explanation of the two earnings management and four investor protection variables.

\subsection{The variables of accrual-based and real earnings management}

Earnings management is classified into AEM and REM. This paper explores the relationship between the two types of earnings management and investor protection. We calculate three measures for AEM and two measures for REM, then aggregate the results.

Though our country-level earnings management measures may be parsimonious due to the limited amount of balance sheet and income statement information available for each firm from Standard \& Poor's Capital IQ database, we can compare between our results and those in Leuz et al. (2003) by using these measures. We compute and aggregate the measures for each type in order to evaluate each country's level of earnings management, avoiding the concerns raised by the calculation methods as much as possible. The measures are ranked from the lowest earnings management level to 
the highest (e.g., the country with the least amount of earnings management is ranked first). The aggregate measure of AEM (REM) is the average rank of the three (two) measures. For aggregation, all the measures should have somewhat similar tendencies.

\subsubsection{The variables of accrual-based earnings management}

Three measures of AEM (of the four used by Leuz et al. [2003]) are employed in this study to indicate the extent of earnings management via accruals. Our explanation of the three measures was drawn from Leuz et al. (2003). As we concentrate on the comparison between AEM and REM, the "small loss avoidance" in Leuz et al. (2003) is not adopted. ${ }^{4}$

Following Dechow et al. (1995), accruals are calculated as follows: ${ }^{5}$

$$
\text { Accruals }(A c c)=\left(\Delta C A_{i t}-\Delta C a s h_{i t}\right)-\left(\Delta C L_{i t}-\Delta S T D_{i t}-\Delta T P_{i t}\right)-\text { Dep }_{i t}
$$

where $\Delta C A_{i t}$ is change in total current assets, $\Delta C a s h_{i t}$ is change in cash and cash equivalents, $\Delta C L_{i t}$ is change in total current liabilities, $\triangle S T D_{i t}$ is change in short-term debt included in current liabilities, $\Delta T P_{i t}$ is change in income taxes payable, and $D_{e p}$ it is depreciation and amortization expense. The subscripts " $i$ " and "t" refer to firm i and year t. We can obtain operating cash flow (CFO) by subtracting accruals from earnings $(C F O=$ Earnings - Accruals $)$. We do not directly compute accruals from the cash flow statement because the data are not available in the cash flows of all the countries in the sample. For reliability, our statistical analysis eliminates outliers, trimming the firm-years within the top and bottom $1 \%$ of the accrual and operating cash flow data. All of the variables used to compute the measures of AEM and REM are divided by total assets at the beginning of the year.

The first measures of AEM are the standard deviation of operating earnings divided by the standard deviation of operating cash flow (AEM1). This measure assumes that a manager might use accruals to mitigate the variation of operating cash flow. If this occurs, this measure becomes smaller.

\footnotetext{
${ }^{4}$ In this study, we focus on the managers' choice of AEM and/or REM. However, "small loss avoidance” in Leuz et al. (2003) does not mean the use of AEM only. Firms might avoid losses by using REM (e.g., Roychowdhury, 2006).

${ }^{5}$ We use the balance sheet approach to calculate accruals. This approach provides more data availability than the cash flow statement approach because our sample period starts in 1991.
} 
$A E M 1$ is calculated using the time-series data of each firm, and the median of $A E M 1$ in each country is its representative value: 6

$$
A E M 1=\frac{\sigma(E)}{\sigma(C F O)}
$$

where $\sigma(E)$ is the standard deviation of the operating income and $\sigma(C F O)$ is the standard deviation of the operating cash flows.

The second measure is the correlation between the changes in accruals and changes in operating cash flow (AEM2). As is well known, the correlation is negative. However, we employ it as an AEM measure because the large magnitudes of the correlation can be interpreted as income-smoothing behavior. AEM2 is computed from the pooled data in each country:

$$
A E M 2=\rho(\triangle A C C, \triangle C F O)
$$

where $\triangle A c c$ is change in accruals, and $\triangle C F O$ is change in operating cash flows.

The third measure is the ratio of the absolute value of accruals to the absolute value of operating cash flows (AEM3). Accruals are reflected in various kinds of manager behaviors intended to achieve certain earnings targets. Therefore, we use the absolute value of accruals as an earnings discretion measure. We divide by the operating cash flow to control for firm size and performance. AEM3 is calculated in each firm-year, and we use each country’s median data:

$$
A E M 3=\frac{|A C C|}{|C F O|}
$$

where $|A c c|$ is the absolute value of accruals and $|C F O|$ is the absolute value of operating cash flows.

$A E M 1$ and $A E M 2$ are employed as smoothing measures, and $A E M 3$ is the measure of discretion used by Leuz et al. (2003). We regard these three measures as the degree of earnings management through accruals.

\footnotetext{
${ }^{6}$ The standard deviations of $C F O$ and Operating Income $(\sigma(C F O)$ and $\sigma(E))$ are computed using a minimum of three years of data per firm and a maximum of 20 years, which are maximally available in our dataset.
} 


\subsubsection{The variables of real earnings management}

Earnings numbers can be managed not only through AEM but also through REM. Following Roychowdhury (2006), Cohen et al. (2008), and Cohen and Zarowin (2010), this paper investigates three types of REM: (1) sales manipulation through price discounts and lenient credit terms, (2) the reduction of discretionary expenditures such as R\&D costs, and (3) overproduction to report lower cost of goods sold.

According to Roychowdhury (2006), sales manipulation through price discounts and lenient credit terms and overproduction lead to abnormally high "production costs" relative to sales. ${ }^{7}$ Thus, sales manipulation and overproduction induce an imbalance in production costs and sales, resulting in a lower correlation between the change in production costs and the change in sales. We therefore use the contemporaneous correlation between the change in production costs and the change in sales (indicated by REM1) as measures of sales manipulation and overproduction. REM1 is computed from the pooled sample in each country; a lower REM1 means that more sales manipulation and/or overproduction has been carried out: ${ }^{8}$

$$
\text { REM1 }=\rho(\text { Prod, } \text { SSales })
$$

\footnotetext{
7 We use "production costs" not generally but in the specific context of Roychowdhury (2006), who defines them as the sum of the costs of goods sold and change in inventory. Roychowdhury (2006) also points out that sales manipulation and overproduction lead to an abnormally low cash flow from operation, while the reduction of discretionary expenses leads to an abnormally high cash flow from operation. Therefore, the net effect on cash flow from operation by REM is ambiguous, as stated in Roychowdhury (2006). Consequently, consistent with Gunny (2010) and Zang (2012), we do not use the proxy with cash flow from operation in the main analysis. The results including the proxy with the cash flow measure are presented in footnote 23.

${ }^{8}$ When a firm engages simultaneously in overproduction and sales manipulation through price discounts, the increase of both $\triangle$ Sales and $\triangle P$ Prod leads to a large value of REM1. However, owing to price discounts, the increase in sales is lower than the increase in production cost. As a result, when a firm engages simultaneously in overproduction and sales manipulation, its $R E M 1$ becomes lower than that in the case of normal sales and production activity. When a firm engages simultaneously in both manipulations, its REM1 could be higher than that of a firm that engages in either sales manipulation or overproduction. It may thus be difficult, using our correlation-based index, to detect the simultaneous intentional overproduction and sales manipulation through discounts. However, a simultaneous increase of $\triangle$ Sales and $\Delta$ Prod might result when a firm decreases unit production cost through mass production and carries out mass sales with lower prices. It might also be interpreted to indicate more normal business activities than when either $\Delta$ Sales or $\Delta$ Prod changes abnormally. In our robustness check, we use the Roychowdhury (2006) model, which allows us to analyze the effect of the simultaneous practice of intentional overproduction and sales manipulation through discounts.
} 
where $\Delta$ Prod is change in production costs, production costs is cost of goods sold plus change in inventory, and $\Delta$ Sales is change in sales.

The reduction of discretionary expenditures to manage earnings should lead to abnormally low discretionary expenses (Roychowdhury, 2006). Therefore, such behavior would result in a departure from normal levels of discretionary expenses. Based on previous studies' expression of discretionary expenses as a linear function of sales (Dechow et al., 1998; Roychowdhury, 2006), we employ the contemporaneous correlation between the change in discretionary expenses and the change in sales (REM2) as a proxy for a reduction of discretionary expenditures. If discretionary expenditures are reduced to manage earnings, REM2 should show a lower value. ${ }^{9}$ We define discretionary expenses as selling, general, and administrative expenses (SG\&A), which frequently include discretionary expenses such as R\&D, advertising, and employee costs. ${ }^{10}$ REM2 is also computed from the pooled sample in each country:

$$
\text { REM2 }=\rho(\Delta D E, \text { SSales })
$$

where $\triangle D E$ is change in selling, general, and administrative expenses.

\subsection{The variables of investor protection}

\subsubsection{Outside investor rights}

Following Leuz et al. (2003), we adopt the anti-director right index created by La Porta et al. (1998) as variables pertaining to outside (minority) investor protection. The index indicates the extent to which outside investors' opinions can be heard during shareholders' meetings; it is calculated by adding 1 when (1) the country allows shareholders to mail their proxy vote to the firm, (2) shareholders

\footnotetext{
9 REM through sales, discretionary expenditures, and production activities may also be engaged to decrease earnings numbers (Francis et al., 2011). Even then, the change in production cost and discretionary expenses deviate from normal levels relative to sales, and the values of REM1 and REM2 should be lower.

10 Based on the definition of the data items in Capital IQ, SG\&A already includes R\&D and advertising costs. It is similar to the definition used in previous research such as Roychowdhury (2006) and Cohen et al. (2008), who aggregate SG\&A, R\&D and advertising costs. Bartov and Cohen (2009) and Gunny (2010) also use the abnormal levels of SG\&A as a proxy for REM.
} 
are not required to deposit their shares prior to the general shareholders' meeting, (3) cumulative voting or proportional representation of minorities in the board of directors is allowed, (4) an oppressed minorities mechanism is in place, (5) the minimum percentage share of capital that entitles a shareholder to call for an extraordinary shareholders' meeting is less than or equal to $10 \%$ (the sample median), or (6) shareholders have preemptive rights that can be waived only by a shareholders' vote. In our study, the index ranges from 0 to 5. Leuz et al. (2003) show that strong and well-enforced outsider rights limit the acquisition of private control benefits by insiders, thus reducing insiders' incentives to engage in AEM. Based on the argument of Leuz et al. (2003) and the discussion in section 2, we predict that the rights of outside investors negatively affect AEM and positively or negatively affect REM.

\subsubsection{Legal enforcement}

The research on investor protection addresses legal enforcement. As La Porta et al. (1998) point out, "a strong system of legal enforcement could substitute for weak rules.” Employing the framework of La Porta et al (1998), Leuz et al. (2003) suggests legal enforcement as the institutional factor influencing AEM. Following Leuz et al. (2003), we measure Legal Enforcement as the mean score across three legal variables used by La Porta et al. (1998): (1) the efficiency of the judicial system, (2) an assessment of rule of law, and (3) the corruption index, all three ranging from 0 to 10 . Similar to the rights of outside investors, legal enforcement is negatively related to AEM and positively or negatively related to REM.

\subsubsection{Disclosure regulations}

Disclosure regulations play an important role in investor protection because less information is available to minority investors than to insiders, and the former have to depend on the information that firms are required to disclose. We predict that, since it is difficult to implement AEM in countries with stricter disclosure regulations (which might lower earnings quality), managers tend to apply REM instead. Strict disclosure regulations may discipline a manager's behavior, which would then restrain REM. 
Previous studies have often used two indexes relating to national disclosure regulations (e.g., Jirasakuldech et al., 2011). One is the index of the Center for International Financial Analysis and Research (CIFAR) database, and the other comes from the Doing Business project of the World Bank (the World Bank disclosure index). ${ }^{11}$ We use the latter as the variable for disclosure regulation due to the limited data in the CIFAR index. According to the World Bank, the investor protection index measures three dimensions of the strength of minority shareholder protections against a director's misuse of corporate assets for personal gain. These three dimensions are the (1) transparency of relatedparty transactions (i.e., the extent of disclosure index), (2) liability for self-dealing (the extent of director liability index), and (3) shareholders' ability to sue officers and directors for misconduct (the ease of shareholder suits index). We use the disclosure index from the World Bank as a proxy for the degree of disclosure regulations. ${ }^{12}$ The World Bank disclosure index measures the extent to which investors are protected through the disclosure of ownership and financial information. The index ranges from 0 to 10, with higher values indicating more disclosure.

\subsubsection{Analyst following}

Financial analysts also play a key role in investor protection, as they are important information intermediaries in securities markets (Healy and Palepu, 2001). The extent of analyst following could affect earnings management in a country. Some studies indicate that monitoring and pressure from analysts affect AEM. For example, Yu (2008) and Degeorge et al. (2013) provide evidence that analyst following negatively affects AEM. Because most analysts are undoubtedly highly skilled monitors of AEM, they can make it increasingly difficult for managers to engage in AEM; thus, managers are pressed to carry out REM in the presence of the analysts. In this light, we predict that analyst following has a negative effect on AEM: managers choose REM when the tradeoff between AEM and REM is more powerful than the effect of discipline on them.

\footnotetext{
11 These data can be obtained at the World Bank website, http://data.worldbank.org/ (last accessed March 15, 2014).

12 For example, Ghosh and Revilla (2007) use the disclosure index from the World Bank as one proxy for the quality of investor protection.
} 
In this regard, however, Cohen and Zarowin (2010) find a negative association between analyst following and total earnings management, a metric that includes both AEM and REM. ${ }^{13}$ In addition, Hong et al. (2012) indicate that both AEM and REM are significantly reduced by analyst following. Their results indicate that AEM and REM are restrained because analysts scrutinize and monitor firm activities. ${ }^{14}$ Thus, analysts may pay attention to both accounting and real activity. In this case, both AEM and REM could be reduced.

\subsection{Regression models}

To test the hypotheses on the relationship between the two types of earnings management and investor protection, we constructed the following regression models based on Leuz et al. (2003). Equations (7) to (10) are single regression models, and equation (11) is a multiple regression model that includes the four independent variables used in the single regression models. Following Leuz et al. (2003), we estimate these models by rank regression: ${ }^{15}$

$$
\begin{aligned}
& A E M_{j}\left(\text { or } R E M_{j}\right)=\beta_{0}+\beta_{1} \text { Outside Investor Rights } s_{j}+\varepsilon_{j} \\
& A E M_{j}\left(\text { or } R E M_{j}\right)=\beta_{0}+\beta_{1} \text { Legal Enforcement }_{j}+\varepsilon_{j} \\
& A E M_{j}\left(\text { or } R E M_{j}\right)=\beta_{0}+\beta_{1} \text { Disclosure Index }_{j}+\varepsilon_{j} \\
& A E M_{j}\left(\text { or } R E M_{j}\right)= \beta_{0}+\beta_{1} \text { Analyst Following } \\
& j+\varepsilon_{j} \\
& A E M_{j}\left(\text { or } R E M_{j}\right)=\beta_{0}+\beta_{1} \text { Outside Investor Rights }{ }_{j}+\beta_{2} \text { Legal Enforcement }_{j} \\
&+\beta_{3} \text { Disclosure Index } \\
&
\end{aligned}
$$

where $A E M$ is the aggregate accrual-based earnings management score, $R E M$ is the aggregate real earnings management score, Outside Investor Rights is the anti-director rights index from La Porta et al. (1998), Legal Enforcement is the average score across three legal variables used by La Porta et al.

\footnotetext{
${ }^{13}$ However, they do not compare the relationships of AEM and REM with analyst following.

14 According to Cohen and Zarowin (2010), there are two possible views on analyst following: (1) AEM and REM are restrained because analysts scrutinize and monitor firm activities, or (2) AEM and REM are accelerated because analyst forecasts serve as incentives for managers, who strive to meet or beat them.

15 OLS regressions with unranked variables produce similar results.
} 
(1998), Disclosure Index is the disclosure index from the World Bank ranging from 1 to 10, Analyst Following is the average number of analyst following for all firms in each country, $j$ is country, and $\varepsilon$ is an error term. Under AEM (REM), the predicted signs of the coefficients of Outside Investor Rights, Legal Enforcement, Disclosure Index, and Analyst Following are negative (positive or negative).

\subsection{Sample selection procedure}

Our sample is based on the 49 countries studied by La Porta et al. (1998) and constructed by the listed firms in nonfinancial sectors, covering 1991 to 2010, that were selected from Capital IQ. The former criterion is used to perform a comparison with the many studies that refer to La Porta et al. (1998). To be included in our analysis, the firms had to have available balance sheets and income statements for at least three consecutive years and for the countries (at least 300 firm-years) to allow us to obtain the data required for calculating the representative data from each country. Finally, we excluded the countries that experienced hyperinflation over the sample period, as hyperinflation could seriously affect our earnings management measures. ${ }^{16}$ Argentina, Brazil, Peru, Turkey, Venezuela, and Zimbabwe were thus cut from our sample, leaving a final sample of 222,513 firm-year observations from 38 countries. ${ }^{17}$

Table 1 provides the descriptive statistics for each country. It shows the number of firm-years in each country and year. Our total sample size $(222,513)$ is much larger than that of Leuz et al. (2003) due to the extended sample periods and the use of Capital IQ. The rightmost column shows the number of firm-years in each country: the United States has the largest at 53,072, followed by Japan, India, and Canada. Nigeria has the smallest at 300. The bottom row provides the number of firm-years in each year, the smallest of which was in 1991 and the highest in 2010. In general, the available observations

\footnotetext{
${ }^{16}$ We define hyperinflation as inflation over $100 \%$ per year. Since hyperinflation heavily influences our measures over the long term, we exclude this data.

17 Our sample is limited by the coverage in Capital IQ. The data we obtained may be biased toward larger firms and/or higher developed countries. As shown in Table 1, for some countries, data availability is low before year 2000. There is room for argument on the database used by the study. See Garcia Lara et al. (2006) for further discussion on global databases.
} 
increase annually. Canada and India, for example, had scant data in the early 1990s; after the second half of the decade, however, a large amount of data was included in Capital IQ.

[Insert Table 1 here]

\section{Empirical results}

\subsection{Descriptive statistics}

Table 2 shows the scores for AEM and REM. Panel A provides three AEM measures and their aggregated score — the average rank of three measures (rightmost column). Lower AEM1 and AEM2 scores imply that accrual management is used to reduce the variations in earnings and conceal economic shocks to the firm's CFO. For AEM1, Australia has the highest score. Portugal has the lowest score, followed by Italy, Spain, France, and Austria. This tendency is maintained in AEM2. Both measures are higher in Anglo-American countries than in Asia and Continental Europe, indicating that AngloAmerican countries employ the lower extent of AEM. AEM3 (accruals divided by CFO) is reflected in various manager behaviors as their attempt to achieve specific earnings targets. All three variablesAEM1, AEM2, and AEM3-have similar tendencies. ${ }^{18}$ Therefore, we may use the aggregated AEM score $(A E M)$, which is the average rank of the three measures.

[Insert Table 2 here]

$R E M 1$ is the extent to which overproduction for earnings management is pervasive in a country.

As shown in Panel B, Japan posts the lowest level of earnings management (0.928), followed by South Korea, Taiwan, Austria, and Greece. The mean is 0.787.

REM2 is the correlation between the change in sales and the change in discretionary expenses. If discretionary expenses are rarely curtailed, REM2 is expected to rise, as discretionary expenses

\footnotetext{
18 In our research, the calculation of $A E M 1, A E M 2$, and $A E M 3$ is related to that of $E M 1, E M 2$, and EM3, as in Leuz et al. (2003). The country scores seem to be similar to those in Leuz et al. (2003) overall. The calculated means of AEM1 and AEM2 are close to those of $E M 1$ and $E M 2$. However, $A E M 3$ and EM3 have a comparatively large difference of 0.25, possibly due to the extended sample periods.
} 
typically increase in proportion to sales. The balance between sales and discretionary expenses is negatively affected when the former is managed. The results of REM2 are similar to those of REM1. REM2 shows that Oceanic countries tend to employ REM more than AEM. ${ }^{19}$

The rightmost column of Panel B shows the aggregated score of the REM measures. The result of REM2 is also similar to that of REM1. Hence, we may calculate the aggregated REM score (REM) the same way we calculated AEM.

Table 3 contains the institutional variables for the regression analysis of the 38 countries. Outside Investor Rights and Legal Enforcement are similar to those in Leuz et al. (2003). A characteristic of Disclosure Index is that not all the developed countries do have high scores (e.g., Germany’s index is five). Overall, the Analyst Following of European countries is relatively high. The two variables are added to the Leuz et al. (2003) model and tested for association with AEM and REM.

[Insert Table 3 here]

Table 4 provides the correlation matrix for the $A E M, R E M$, and investor protection variables. $A E M$ is negatively correlated to REM, and the $p$-value is under 5\% (two-tailed). These results imply the substitutability between AEM and REM. The correlation between AEM (REM) and Outside Investors Rights is significantly negative (positive). These results are consistent with our predictive analysis. ${ }^{20}$

[Insert Table 4 here]

\subsection{Regression results}

Panels A and B of Table 5 show the regression results. In Section 2, we hypothesized that AEM is constrained in countries with better investor protection but that REM implementation may increase or decrease. Higher values for all of the independent variables (Outside Investor Rights, Legal Enforcement, Disclosure Index, and Analyst Following) lead to better investor protection. Thus, the

\footnotetext{
19 Australia's lower AEM and higher REM is a typical case that supports our prediction. The results might be affected by the characteristics of Australia's data, such as industrial composition. However, as countries with different industry compositions (e.g., Hong Kong) show similar results, the effects of industrial composition do not dominate our results.

${ }^{20}$ AEM1, AEM2, and AEM3 are highly correlated with each other. The correlation between REM1 and REM2 is also high. Therefore, the use of the aggregated AEM score (AEM) and REM (REM) are justified.
} 
predicted signs for the coefficient of these variables are negative when the dependent variable is $A E M$. When REM is the dependent variable, no signs for the coefficients of these variables are predicted under the null hypothesis (H2).

Since the results of the single and multiple regressions are similar in Panels A and B, we describe the results only of the multiple regressions. Panel A contains the results for AEM. As predicted and consistent with Leuz et al. (2003), the coefficients of Outside Investor Rights and Legal Enforcement are significantly negative. These results support $\mathrm{H} 1$ and indicate that AEM is less prevalent in countries with better investor protection. However, the coefficients of Disclosure Index and Analyst Following are insignificant. ${ }^{21}$

Panel B shows the results for REM. As expected, they are contrary to the results for $A E M$. The coefficient of Outside Investor Rights is significantly positive, indicating that REM is more prevalent in countries with better outside investor rights. The coefficient of Legal Enforcement is not significant. As with the results for AEM, the coefficient of Disclosure Index is insignificant. In contrast to the results for AEM, the coefficient of Analyst Following is significantly negative. This result is consistent with Cohen and Zarowin (2010), who find a negative association between analyst following and earnings management. ${ }^{22}$ This finding is consistent with the notion that analyst monitoring influences managers' behavior and limits REM. ${ }^{23}$

The results in this section indicate that AEM is more constrained in countries with better investor protection. Managers in countries with better outside investor rights tend to engage in REM instead of AEM. The coefficient of Analyst Following is insignificant for AEM, while REM is more constrained

\footnotetext{
${ }^{21}$ The relationship between analyst following and AEM is not similar to that in Yu (2008). However, the analysis of Yu (2008) is based on firm-year data.

22 The result of Legal Enforcement is not consistent with that seen in Table 4. We infer that the result is controlled by other variables.

${ }^{23}$ Following Roychowdhury (2006), we add the third measure based on abnormal cash flow from operations to REM1 and $R E M 2$. It is computed as the correlation between the change in CFO and the change in sales, $\rho(\triangle C F O, \triangle S A L E S)$. When we recalculate the REM measure, the coefficient of Analyst Following remains negatively significant, but that of Outside Investor Rights is not significant, possibly because the effects of overproduction and of the reduction of discretionary expenses are mixed, as noted in footnote 7.
} 
by analyst following. The former result occurs because analyst following may have restraining and accelerating effects on AEM. Analyst following not only restrains AEM through manager monitoring but also accelerates it by inducing earnings management incentives for managers to meet an analyst's earnings forecast. Because these effects offset each other, the coefficient of Analyst Following has insignificant value for AEM. Analysts are sophisticated and very likely to closely monitor REM activity that could destroy a firm's value. Analysts could induce managers' earnings management incentives to achieve an analyst's earnings forecast, but managers tend not to engage in value-destroying REM when many analysts are following.

Thus, managers tend to engage in REM where the legal environment curbs AEM, and the development of security markets increases the monitoring of managerial discretionary behaviors. However, there is no evidence of a relationship between AEM (REM) and the disclosure index level.

[Insert Table 5 here]

\section{Robustness checks}

We conduct additional analyses to check the robustness of our findings. Leuz et al. (2003) pointed out the endogeneity bias between outside investor protection and earnings management. We conducted further analyses using a two-stage least squares estimation (2SLS) to address endogeneity. Following Leuz et al. (2003), legal origins and per capita GDP are employed as instrumental variables for Outside Investor Rights and Legal Enforcement. Legal origin refers to the basis of the legal system of each country. Legal origin is determined involuntarily in many countries through processes such as occupation and colonization. Per capita GDP is employed because the construction and maintenance of various legal systems require national wealth. We therefore use legal origin and per capita GDP as instrumental variables. Legal Origin Code (English, French, German, or Scandinavian legal origins) is based on the classifications in La Porta et al. (1998) and is transformed into three dummy variables. Per Capita GDP is computed as the average per capita GDP from 1981 to 1990 in each country and 
converted to a ranked variable. Table 6 presents the results from the 2SLS. When the dependent variable is AEM, the coefficient of Outside Investor Rights is significantly negative but that of Legal Enforcement is not significant. For REM, the coefficient of Outside Investor Rights is significantly positive, but the coefficient of Analyst Following is not significant. This shows that the potential endogeneity issue is not completely resolved. ${ }^{24}$ However, the results for Outside Investor Rights do not change qualitatively.

[Insert Table 6 here]

Previous research considers Big 4 audits (Francis and Wang, 2008) as factors that could affect earnings management. We re-estimate equation (11), including the ratio of companies audited by Big 4 firms in each country as an additional independent variable (indicated by Big4 Ratio). ${ }^{25}$ The rank regression results, including the Big4 Ratio, are presented in Table 7. Although the coefficients of the Big4 Ratio are not significant, the coefficients of the other variables are essentially similar to those in the previous section. Hence, the results in the previous section are robust when we add the regression models to the Big4 Ratio.

\section{[Insert Table 7 here]}

The third robustness check uses the abnormal discretionary expenses and production costs developed by Roychowdhury (2006). The standard deviations are employed as proxies of the level of earnings management in each country. These measures are based on the methods developed by Dechow and Dichev (2002).

\footnotetext{
24 The results of the first-stage regressions show that almost all of the coefficients of Legal Origin Code are significant in both of the equations of the first stage. Per Capita GDP is significantly positive in the equation for Legal Enforcement but not significant in that for Outside Investors Rights. Moreover, we carried out a Durbin-Wu-Hausman test to check the endogeneity of Outside Investor Rights and Legal Enforcement. The test rejected the null of the instruments being exogenous at the $5 \%$ (regression for $A E M$ ) and 10\% (regression for REM) levels.

${ }^{25}$ We exclude the Big4 Ratio from the main regression models to ensure the sample size as much as possible in the main analysis.
} 
To obtain the abnormal level of production costs (A_Prod) and discretionary expenses ( $\left.A \_D E\right)$, our estimations use the following regression models estimated for each industry-year combination in each country, where industry is identified by a two-digit SIC code:

$$
\begin{gathered}
\left.\operatorname{Prod}_{i j t} / \text { Asset }_{i j t-1}=\beta_{0}+\beta_{1}\left(1 / \text { Asset }_{i t-1}\right)+\beta_{2} \text { Sales }_{i j t} / \text { Asset }_{i j-1}\right)+\beta_{3}\left(\text { Sales }_{i j t} / \text { Asset }_{i j t-1}\right) \\
+\beta_{4}\left(\Delta \text { Sales }_{i j t-1} / \text { Asset }_{i j t-1}\right)+\varepsilon_{i j t} \\
\operatorname{DE}_{i j t} / \text { Asset }_{i j t-1}=\beta_{0}+\beta_{1}\left(1 / \text { Asset }_{i j t-1}\right)+\beta_{2}\left(\text { Sales }_{i j t-1} / \text { Asset }_{i j t-1}\right)+\varepsilon_{i j t}
\end{gathered}
$$

Standard deviations of $A \_P r o d$ and $A \_D E$ are computed from the pooled samples from each country ( $\sigma\left(A \_\right.$Prod $)$and $\left.\sigma\left(A \_D E\right)\right)$, used as the country-level representative value. A higher value of standard deviation indicates more REM. The aggregated REM score (REM_Roy) is computed as the average rank of $\sigma\left(A \_D E\right)$ and $\sigma\left(A \_D E\right)$.

Table 8 shows the rank regression results using REM_Roy. While Analyst Following has an insignificant coefficient, the coefficients of Outside Investor Rights and Legal Enforcement are significantly positive, indicating that REM is more implemented in countries with stronger investor protection. Roychowdhury's (2006) model leads to smaller sample sizes in countries. For example, Jordan has the fewest observations, at only 33, owing to the requirements for the estimation of $A \_P r o d$ and $A \_D E$. New Zealand, Ireland, and Austria have also fewer than 100 observations. The A_Prod and A_DE requirement for at least 300 observations in each country excludes 10 countries from our sample. The results of reduced sample remain similar, as seen in Table 8 .

\section{[Insert Table 8 here]}

In Section 4.2, we follow Leuz et al. (2003) and compute the legal enforcement score as the average across three variables used in La Porta et al. (1998): (1) the efficiency of the judicial system, (2) an assessment of rule of law, and (3) the corruption index. ${ }^{26}$ In this section, we create a new legal

\footnotetext{
26 The first variable ranges from 0 to 10 and the second and third variables from -2.5 to +2.5 .
} 
enforcement variable using data available for the sample period and re-estimate equation (5). In particular, to re-compute the value of Legal Enforcement, we replace an assessment of the rule of law and the corruption index with their counterparts from the year 2000, based on Kaufmann et al. (2004) or Kaufmann et al (2009). Table 9 shows the rank regression results using the new proxy for legal enforcement by Kaufmann et al. (2004). ${ }^{27}$ The results are the same as before and are thus robust when substituted with the variable of Legal Enforcement. ${ }^{28}$

[Insert Table 9 here]

Next, based on the aggregation of earnings management by country shown in Table 5, we analyze the relationship between investor protection and earnings management through 38 observations, which is much smaller than the 222,513 firm-years from the 38 countries in Table 1 . To address this decreased sample size, we use measures of earnings management calculated by country and year and re-estimate equation (11). ${ }^{29}$

The recalculation increases the sample size from 38 to 515. To run the regression equation (11), two types of earnings management measures are ranked in the pooled data and converted from 1 to 38 . In addition, we add year indicator variables to equation (11) to control for year effects. The results in Table 10 are similar to those in Table 5 for AEM; for REM, however, the coefficient of Legal Enforcement is significantly positive at a marginal level, and the coefficient of Disclosure Index is significantly positive. Thus, the results of this additional analysis corroborate the results of the previous analyses.

[Insert Table 10 here]

\footnotetext{
27 The results in Kaufmann et al. (2009) are also similar as before.

${ }^{28}$ Furthermore, when the disclosure index is replaced by Disclosure Requirement in La Porta et al. (2006), the results are also similar to those shown in Table 5.

${ }^{29}$ Because each country-year requires at least 30 observations to obtain two earnings management measures, the amount of the data for each country is unbalanced (for example, Japan has data for 19 years, whereas Nigeria has data only for three years). Hence, we do not adopt country-year-based analysis as the primary analysis.
} 


\section{Conclusion}

This paper examined the relationships between earnings management and investor protection across 38 countries. Our tests were based on data of 222,513 firm-year observations covering 1991 to 2010. Leuz et al. (2003) show that strong investor protection limits earnings management. While their measures of earnings management are mainly accrual-based, we focused on both AEM and REM.

First, following Leuz et al. (2003), Yu (2008), and Degeorge et al. (2013), we hypothesized that AEM is more constrained in countries with stronger investor protection. Next, we formulated two hypotheses for REM: the first is that REM is more often implemented in countries with stronger investor protection because of the substitution between AEM and REM; the second is that, since REM is likely to negatively affect a firm's future operating performance and to be restrained through discipline on managers in the same way as AEM, REM is more constrained in countries with stronger investor protection.

Our results are consistent with the substitution effect between AEM and REM and indicate that outside investor rights are negatively correlated to AEM and positively correlated to REM. However, we also provide evidence that the more analysts investigate firms, the less REM is carried out, consistent with the argument that REM is restrained through the discipline by analyst following. The results do not change under the control of audit quality, alternative definitions of the investor protection variables, or the use of AEM and REM measures calculated by country and year.

REM is a "departure from normal operational practices” (Roychowdhury, 2006, 337) and will likely impact future performance negatively. For example, Bhojraj et al. (2009) suggest that the effort to meet or beat analyst forecasts by using AEM and REM has a negative effect on a firm's future ROA and stock price.

Our results show that strong investor protection restricts AEM and imply that a strong legal environment, which is outside investor rights, heightens the risk of firm value reduction via REM, while 
the presence of analysts as investor protection is effective in monitoring REM. We show the substitution effect between AEM and REM in terms of outside investor rights at the country level.

As with prior research, we use a parsimonious model to calculate the proxies for AEM and REM due to the limited data available from Capital IQ. Future research is required to improve the model and estimate AEM and REM using detailed international accounting data. Furthermore, we should attempt to overcome the endogeneity problem by incorporating more appropriate models in future research because some of our results are not supported in the 2SLS test for robustness.

\section{Acknowledgments}

We appreciate the helpful comments from Bin Srinidhi (editor), an anonymous referee, Steven Dellaportas, Makoto Nakano, Masumi Nakashima, Akinobu Shuto, Alfred Wagenhofer, Tatsushi Yamamoto, and workshop participants at the 13th Annual Conference of the Asian Academic Accounting Association (AAAA), the 6th International Workshop on Accounting and Regulation, Kobe University, and Osaka University. We gratefully acknowledge the financial support of the Japan Securities Scholarship Foundation and the Ishii Memorial Securities Research Promotion Foundation. 


\section{References}

Bartov, E., Cohen, D. A., 2009. The "numbers game” in the pre-and post-Sarbanes-Oxley eras. J. Account. Audit. Financ. 24, 505-534.

Bhojraj, S., Hribar, P., Picconi, M., Mcinnis, J., 2009. Making sense of cents: An examination of firms that marginally miss or beat analyst forecasts. J. Financ. 64, 2361-2388.

Boonlert-U-Thai, K., Meek, G. K., Nabar, S., 2006. Earnings attributes and investor-protection: International evidence. Int. J. Account. 41, 327-357.

Chen, J. Z., Rees, L. L., Sivaramakrishnan, S., 2010. On the use of accounting vs. real earnings management to meet earnings expectations-A market analysis. Working paper. Available at SSRN: http://ssrn.com/abstract=1070122.

Cohen, D., Dey, A., Lys, T., 2008. Real and accrual based earnings management in the pre and post sarbanes oxley periods. Account. Rev. 83, 757-787.

Cohen, D. A., Zarowin, P., 2010. Accrual-based and real earnings management activities around seasoned equity offerings. J. Account. Econ. 50, 2-19.

Dechow, P. M., Dichev, I. D., 2002. The quality of accruals and earnings: The role of accrual estimation errors. Account. Rev. 77, 35-59.

Dechow, P. M., Kothari, S. P., Watts, R. L., 1998. The relation between earnings and cash flows. J. Account. Econ. 25, 133-168.

Dechow, P. M., Sloan, R. G., Sweeney, A. P., 1995. Detecting earnings management. Account. Rev. 70, $193-225$.

Degeorge F., Ding Y, Jeanjean T., Stolowy H. 2013. Analyst coverage, earnings management and financial development: An international study. J. Account. Public. Policy. 32, 1-25.

Ewert, R., Wagenhofer, A., 2005. Economic effect of tightening accounting standards to restrict earnings management. Account. Rev. 80, 1101-1124. 
Francis, J., Wang, D., 2008. The joint effect of investor protection and Big 4 audits on earnings quality around the world. Contemporary. Account. Res. 25, 157-191.

Francis, B., Hasan, I., Li, L., 2011. A cross-country study of legal environment and real earnings management. Working paper. Available at SSRN: http://ssrn.com/abstract= 1740036 .

García Lara, J. N., García Osma, B., Gill de Albornoz, B., 2006. Effects of database choice on international accounting research. Abacus. 42, 426-454.

Ghosh, S., Revilla, E., 2007. Enhancing the efficiency of securities markets in East Asia. World Bank Policy Research Working Paper 4129, 1-27. Available at the World Bank e-library. http://elibrary.worldbank.org/doi/pdf/10.1596/1813-9450-4129.

Gordon, E. A., Greiner, A., Kohlbeck, M., Lin, S., Skaife, H., 2013. Challenges and opportunities in cross-country accounting research. Account. Horiz. 27, 141-154.

Graham, J. R., Harvey, C. R., Rajgopal, S., 2005. The economic implications of corporate financial reporting. J. Account. Econ. 40, 3-73.

Gunny, K. 2010. The relation between earnings management using real activities manipulation and future performance: Evidence from meeting earnings benchmarks. Contemporary. Account. Res. 27, 855-888.

Healy, P. M., Wahlen, J. M., 1999. A review of the earnings management literature and its implications for standard setting. Account. Horiz. 13, 365-384.

Healy, P. M., Palepu, K., 2001. A review of the empirical disclosure literature. J. Account. Econ. 31, $405-440$

Hong, Y., Huseynov, F., Zhang, W., 2012. Earnings management and analyst following: A simultaneous equations analysis. Working Paper. Available at SSRN: http://ssrn.com/abstract=2139559.

Jirasakuldech, B., Zorn, T., Geppert, J., Dudney, D., 2011. Financial disclosure, investor protection, and stock market behavior: an international comparison. Rev. Quantitative Fin. Account. 37, 181-205. 
Kaufmann, D., Kraay, A., Mastruzzi, M., 2004. Governance matters III: Governance indicators for 1996, 1998, 2000, and 2002. World Bank Econ Rev. 18, 253-287.

Kaufmann, D., Kraay, A., Mastruzzi, M., 2009. Governance matters VIII: Aggregate and individual governance indicators 1996-2008. World Bank Policy Research Working Paper No. 4978. Available at SSRN: http://ssrn.com/abstract=1424591

Kim, J., Sohn, B. C., 2013. Real earnings management and cost of capital. J. Account. Public. Policy. 32, 518-543.

Kothari, S. P., Mizik, N., Roychowdhury, S., 2012. Managing for the moment: The role of real activity versus accruals earnings management in SEO valuation. Working Paper. Available at SSRN: http://ssrn.com/abstract=1982826.

La Porta, R., Lopez-de-Silanes F., Shleifer, A., Vishny R., 1997. Legal determinants of external finance. J. Financ. 52, 1131-1150.

La Porta, R., Lopez-de-Silanes F., Shleifer, A., Vishny R., 1998. Law and finance. J. Polit. Econ. 106, $1113-1155$.

La Porta, R., Lopez-de-Silanes F., Shleifer, A., Vishny R., 2002. Investor protection and corporate Valuation. J. Financ. 75, 1147-1170.

La Porta, R., Lopez-de-Silanes F., Shleifer A., 2006. What works in securities laws? J. Financ. 61, 132.

Leuz, C., Nanda, D., Wysocki, P., 2003. Earnings management and investor protection: an international comparison. J. Financ. Econ. 69, 505-527.

Roychowdhury, S., 2006. Earnings management through real activities manipulation. J. Account. Econ. 42, 335-370.

Shen, C. H., Chih, H. L., 2005. Investor protection, prospect theory, and earnings management: An international comparison of the banking industry. J. Bank. Financ. 29, 2675-2697.

Yu, F., 2008. Analyst coverage and earnings management. J. Financ. Econ. 88, 245-271. 
Wysocki, P., 2004. Discussion of ultimate ownership, income management, and legal and extra-legal institutions. J. Account. Res. 42, 463-474.

Wysocki, P., 2011. New institutional accounting and IFRS. Account. Bus. Res. 41, 309-328.

Zang, A. Y. 2012. Evidence on the trade-off between real activities manipulation and accrual-based earnings management. Account. Rev. 87, 675-703. 
Table 1

Firm-year observations in each country.

\begin{tabular}{|c|c|c|c|c|c|c|c|c|c|c|c|c|c|c|c|c|c|c|c|c|c|}
\hline Country & 1991 & 1992 & 1993 & 1994 & 1995 & 1996 & 1997 & 1998 & 1999 & 2000 & 2001 & 2002 & 2003 & 2004 & 2005 & 2006 & 2007 & 2008 & 2009 & 2010 & Total \\
\hline Australia & 45 & 49 & 50 & 52 & 53 & 52 & 65 & 107 & 244 & 278 & 368 & 491 & 626 & 686 & 706 & 748 & 816 & 811 & 915 & 1,003 & 8,165 \\
\hline Austria & 10 & 14 & 14 & 15 & 15 & 13 & 14 & 25 & 31 & 42 & 49 & 49 & 54 & 57 & 57 & 57 & 58 & 61 & 60 & 59 & 754 \\
\hline Belgium & 16 & 16 & 16 & 17 & 15 & 22 & 17 & 27 & 36 & 61 & 66 & 66 & 66 & 69 & 78 & 91 & 94 & 88 & 89 & 88 & 1,038 \\
\hline Canada & 2 & 2 & 3 & 6 & 10 & 27 & 201 & 463 & 555 & 656 & 716 & 736 & 840 & 864 & 914 & 952 & 1,043 & 1,012 & 1,083 & 1,146 & 11,231 \\
\hline Chile & 13 & 14 & 24 & 26 & 29 & 37 & 35 & 40 & 70 & 84 & 89 & 101 & 110 & 114 & 115 & 119 & 123 & 127 & 129 & 130 & 1,529 \\
\hline Denmark & 28 & 28 & 28 & 26 & 26 & 28 & 33 & 44 & 54 & 70 & 80 & 83 & 86 & 86 & 88 & 92 & 95 & 95 & 95 & 92 & 1,257 \\
\hline Finland & 25 & 25 & 27 & 26 & 28 & 27 & 30 & 43 & 50 & 74 & 88 & 91 & 97 & 98 & 100 & 101 & 102 & 104 & 105 & 107 & 1,348 \\
\hline France & 95 & 99 & 100 & 100 & 100 & 122 & 122 & 176 & 223 & 303 & 341 & 360 & 402 & 430 & 460 & 495 & 509 & 508 & 513 & 518 & 5,976 \\
\hline Germany & 113 & 115 & 115 & 111 & 111 & 100 & 110 & 184 & 260 & 343 & 414 & 419 & 462 & 470 & 499 & 541 & 555 & 548 & 537 & 524 & 6,531 \\
\hline Greece & 0 & 0 & 0 & 0 & 0 & 4 & 6 & 26 & 37 & 51 & 58 & 66 & 79 & 83 & 93 & 123 & 138 & 164 & 176 & 183 & 1,287 \\
\hline Hong Kong & 30 & 32 & 48 & 49 & 57 & 86 & 113 & 150 & 246 & 344 & 439 & 579 & 678 & 716 & 760 & 805 & 819 & 836 & 850 & 881 & 8,518 \\
\hline India & 1 & 1 & 4 & 4 & 5 & 7 & 5 & 25 & 37 & 650 & 770 & 875 & 1,098 & 1,585 & 1,770 & 1,889 & 1,978 & 2,050 & 2,125 & 2,306 & 17,185 \\
\hline Indonesia & 0 & 2 & 25 & 28 & 31 & 52 & 63 & 85 & 117 & 125 & 132 & 122 & 126 & 125 & 128 & 143 & 157 & 182 & 196 & 217 & 2,056 \\
\hline Ireland & 18 & 18 & 18 & 18 & 19 & 18 & 21 & 23 & 27 & 28 & 35 & 33 & 40 & 40 & 43 & 44 & 49 & 53 & 54 & 54 & 653 \\
\hline Israel & 0 & 0 & 1 & 2 & 4 & 4 & 5 & 33 & 44 & 65 & 77 & 78 & 102 & 116 & 123 & 142 & 148 & 143 & 165 & 212 & 1,464 \\
\hline Italy & 16 & 16 & 15 & 18 & 20 & 33 & 30 & 56 & 67 & 91 & 121 & 132 & 144 & 153 & 163 & 176 & 191 & 198 & 205 & 207 & 2,052 \\
\hline Japan & 856 & 910 & 954 & 979 & 1,017 & 1,038 & 1,005 & 1,091 & 1,156 & 1,564 & 1,728 & 1,980 & 2,128 & 2,216 & 2,315 & 2,435 & 2,663 & 3,141 & 3,233 & 3,241 & 35,650 \\
\hline Jordan & 0 & 0 & 0 & 0 & 0 & 0 & 0 & 0 & 1 & 3 & 3 & 7 & 45 & 53 & 58 & 67 & 77 & 37 & 34 & 5 & 390 \\
\hline Malaysia & 70 & 73 & 76 & 76 & 80 & 114 & 164 & 200 & 261 & 351 & 429 & 458 & 500 & 542 & 594 & 656 & 707 & 727 & 759 & 788 & 7,625 \\
\hline Mexico & 0 & 0 & 6 & 23 & 15 & 15 & 26 & 41 & 50 & 56 & 63 & 68 & 72 & 77 & 79 & 79 & 81 & 84 & 87 & 88 & 1,010 \\
\hline Netherlands & 35 & 37 & 37 & 37 & 35 & 39 & 46 & 63 & 71 & 89 & 94 & 91 & 99 & 101 & 103 & 104 & 111 & 113 & 115 & 116 & 1,536 \\
\hline New Zealand & 5 & 5 & 5 & 5 & 7 & 9 & 11 & 15 & 22 & 40 & 47 & 53 & 64 & 78 & 83 & 83 & 87 & 85 & 91 & 93 & 888 \\
\hline Nigeria & 0 & 0 & 0 & 0 & 0 & 0 & 1 & 1 & 1 & 0 & 0 & 4 & 13 & 32 & 42 & 56 & 54 & 38 & 31 & 27 & 300 \\
\hline Norway & 18 & 17 & 19 & 19 & 23 & 25 & 21 & 32 & 36 & 51 & 62 & 69 & 81 & 88 & 96 & 109 & 123 & 133 & 144 & 150 & 1,316 \\
\hline Pakistan & 0 & 0 & 0 & 0 & 0 & 11 & 40 & 76 & 97 & 86 & 97 & 74 & 70 & 92 & 110 & 127 & 151 & 160 & 175 & 189 & 1,555 \\
\hline Philippines & 1 & 1 & 5 & 5 & 2 & 3 & 10 & 22 & 37 & 44 & 60 & 63 & 89 & 93 & 96 & 104 & 106 & 103 & 108 & 112 & 1,064 \\
\hline Portugal & 1 & 1 & 2 & 2 & 3 & 9 & 7 & 12 & 12 & 16 & 23 & 27 & 35 & 37 & 38 & 38 & 39 & 40 & 40 & 41 & 423 \\
\hline Singapore & 38 & 38 & 38 & 40 & 49 & 96 & 99 & 115 & 153 & 206 & 258 & 292 & 334 & 360 & 394 & 414 & 425 & 454 & 471 & 491 & 4,765 \\
\hline South Africa & 18 & 18 & 18 & 18 & 18 & 22 & 24 & 40 & 63 & 80 & 109 & 127 & 146 & 149 & 162 & 176 & 187 & 198 & 214 & 222 & 2,009 \\
\hline South Korea & 0 & 0 & 0 & 0 & 104 & 113 & 136 & 149 & 161 & 197 & 298 & 355 & 442 & 534 & 599 & 699 & 1,323 & 1,317 & 1,307 & 936 & 8,670 \\
\hline Spain & 7 & 8 & 28 & 41 & 44 & 47 & 46 & 57 & 64 & 74 & 78 & 83 & 88 & 92 & 99 & 99 & 100 & 103 & 105 & 103 & 1,366 \\
\hline Sri Lanka & 0 & 0 & 0 & 0 & 0 & 0 & 0 & 1 & 2 & 5 & 5 & 5 & 6 & 15 & 18 & 24 & 30 & 71 & 140 & 158 & 480 \\
\hline Sweden & 24 & 25 & 25 & 27 & 26 & 30 & 38 & 77 & 101 & 138 & 157 & 174 & 205 & 225 & 238 & 262 & 301 & 319 & 344 & 366 & 3,102 \\
\hline Switzerland & 55 & 56 & 57 & 57 & 59 & 63 & 60 & 88 & 102 & 128 & 135 & 141 & 152 & 157 & 167 & 171 & 176 & 178 & 180 & 183 & 2,365 \\
\hline Taiwan & 0 & 0 & 0 & 1 & 1 & 1 & 1 & 2 & 16 & 180 & 240 & 296 & 367 & 871 & 985 & 1,033 & 1,192 & 1,323 & 1,399 & 1,461 & 9,369 \\
\hline Thailand & 2 & 2 & 36 & 39 & 43 & 68 & 59 & 72 & 112 & 176 & 209 & 227 & 247 & 271 & 312 & 338 & 353 & 365 & 377 & 390 & 3,698 \\
\hline United & 272 & 279 & 281 & 280 & 281 & 260 & 241 & 346 & 420 & 497 & 542 & 580 & 673 & 697 & 739 & 796 & 865 & 889 & 924 & 954 & 10,816 \\
\hline United States & 246 & 311 & 749 & 1,018 & 1,415 & 1,932 & 2,498 & 2,747 & 2,888 & 2,974 & 3,172 & 3,106 & 3,572 & 3,613 & 3,730 & 3,875 & 3,979 & 3,611 & 3,698 & 3,938 & 53,072 \\
\hline Total & 2,060 & 2,212 & 2,824 & 3,165 & 3,745 & 4,527 & 5,403 & 6,754 & 7,924 & 10,220 & 11,652 & 12,561 & 14,438 & 16,085 & 17,154 & 18,263 & 20,005 & 20,469 & 21,273 & 21,779 & 222,513 \\
\hline
\end{tabular}


Table 2

Score for earnings management.

Panel A: Score for AEM

\begin{tabular}{|c|c|c|c|c|}
\hline \multirow[b]{2}{*}{ Country } & \multicolumn{3}{|c|}{ AEM measures } & \multirow[b]{2}{*}{ Score for $A E M$} \\
\hline & AEM1 & AEM2 & AEMЗ & \\
\hline Australia & 0.704 & -0.532 & 0.421 & 1 \\
\hline South Africa & 0.669 & -0.747 & 0.495 & 4.7 \\
\hline Sweden & 0.665 & -0.659 & 0.579 & 5 \\
\hline United States & 0.563 & -0.614 & 0.606 & 5.7 \\
\hline Canada & 0.647 & -0.564 & 0.635 & 6.3 \\
\hline United Kingdom & 0.504 & -0.690 & 0.561 & 8 \\
\hline Hong Kong & 0.487 & -0.714 & 0.677 & 12.7 \\
\hline New Zealand & 0.504 & -0.813 & 0.576 & 13 \\
\hline Ireland & 0.415 & -0.749 & 0.512 & 13.3 \\
\hline Philippines & 0.545 & -0.783 & 0.727 & 13.3 \\
\hline Finland & 0.533 & -0.816 & 0.662 & 14 \\
\hline Norway & 0.486 & -0.738 & 0.695 & 14.3 \\
\hline Netherlands & 0.434 & -0.781 & 0.616 & 15 \\
\hline Sri Lanka & 0.535 & -0.803 & 0.728 & 15.3 \\
\hline Denmark & 0.463 & -0.777 & 0.689 & 15.7 \\
\hline Mexico & 0.444 & -0.826 & 0.565 & 16 \\
\hline Israel & 0.508 & -0.733 & 0.799 & 16.3 \\
\hline Thailand & 0.494 & -0.832 & 0.663 & 17.3 \\
\hline Switzerland & 0.405 & -0.785 & 0.621 & 18 \\
\hline Chile & 0.451 & -0.839 & 0.607 & 18.3 \\
\hline Pakistan & 0.520 & -0.886 & 0.730 & 21.7 \\
\hline Jordan & 0.422 & -0.801 & 0.759 & 22 \\
\hline Taiwan & 0.511 & -0.854 & 0.780 & 22 \\
\hline India & 0.701 & -0.860 & 0.909 & 23 \\
\hline Malaysia & 0.506 & -0.837 & 0.817 & 23.3 \\
\hline Singapore & 0.425 & -0.803 & 0.787 & 23.3 \\
\hline Belgium & 0.362 & -0.835 & 0.726 & 24.7 \\
\hline Germany & 0.413 & -0.797 & 0.810 & 24.7 \\
\hline Nigeria & 0.464 & -0.916 & 0.751 & 26.3 \\
\hline Austria & 0.351 & -0.847 & 0.735 & 28 \\
\hline Indonesia & 0.417 & -0.846 & 0.821 & 29 \\
\hline Spain & 0.307 & -0.899 & 0.696 & 29.3 \\
\hline
\end{tabular}

\begin{tabular}{|c|c|c|c|}
\hline \multirow[b]{2}{*}{ Country } & \multicolumn{2}{|c|}{ REM measures } & \multirow[b]{2}{*}{ Score for $R E M$} \\
\hline & REM1 & REM2 & \\
\hline Japan & 0.928 & 0.753 & 1 \\
\hline Austria & 0.865 & 0.677 & 4 \\
\hline Мexico & 0.853 & 0.732 & 4.5 \\
\hline Netherlands & 0.859 & 0.651 & 5.5 \\
\hline Greece & 0.861 & 0.645 & 6.5 \\
\hline Switzerland & 0.827 & 0.714 & 7 \\
\hline South Korea & 0.895 & 0.597 & 7.5 \\
\hline Chile & 0.828 & 0.641 & 9.5 \\
\hline Ireland & 0.824 & 0.645 & 10 \\
\hline Belgium & 0.846 & 0.600 & 10.5 \\
\hline Denmark & 0.817 & 0.646 & 11 \\
\hline Taiwan & 0.877 & 0.549 & 11 \\
\hline Thailand & 0.852 & 0.575 & 11.5 \\
\hline Finland & 0.818 & 0.609 & 13 \\
\hline Germany & 0.824 & 0.570 & 15 \\
\hline Indonesia & 0.797 & 0.585 & 16 \\
\hline Spain & 0.782 & 0.640 & 17 \\
\hline Italy & 0.796 & 0.556 & 18.5 \\
\hline Nigeria & 0.825 & 0.479 & 18.5 \\
\hline France & 0.781 & 0.560 & 21 \\
\hline United States & 0.791 & 0.535 & 21 \\
\hline Singapore & 0.796 & 0.456 & 23.5 \\
\hline Israel & 0.774 & 0.517 & 24.5 \\
\hline United Kingdom & 0.765 & 0.524 & 24.5 \\
\hline Norway & 0.788 & 0.451 & 25.5 \\
\hline Portugal & 0.804 & 0.402 & 25.5 \\
\hline India & 0.747 & 0.490 & 26 \\
\hline South Africa & 0.792 & 0.404 & 27 \\
\hline Sweden & 0.733 & 0.483 & 27.5 \\
\hline Hong Kong & 0.776 & 0.422 & 28 \\
\hline Jordan & 0.715 & 0.467 & 29.5 \\
\hline Pakistan & 0.726 & 0.444 & 30.5 \\
\hline
\end{tabular}




\begin{tabular}{|c|c|c|c|c|c|c|c|c|}
\hline France & 0.347 & -0.869 & 0.779 & 30.7 & Malaysia & 0.744 & 0.345 & 33.5 \\
\hline South Korea & 0.383 & -0.869 & 0.877 & 32 & Philippines & 0.644 & 0.412 & 34 \\
\hline Japan & 0.354 & -0.875 & 0.819 & 33 & New Zealand & 0.556 & 0.418 & 34.5 \\
\hline Italy & 0.304 & -0.907 & 0.816 & 34.7 & Canada & 0.695 & 0.372 & 35 \\
\hline Greece & 0.364 & -0.924 & 0.906 & 35 & Sri Lanka & 0.701 & 0.371 & 35 \\
\hline Portugal & 0.243 & -0.932 & 0.798 & 35 & Australia & 0.622 & 0.336 & 37.5 \\
\hline Mean & 0.470 & -0.799 & 0.704 & & Mean & 0.787 & 0.533 & \\
\hline Median & 0.464 & -0.815 & 0.727 & & Median & 0.796 & 0.542 & \\
\hline Std. & 0.110 & 0.094 & 0.116 & & Std. & 0.076 & 0.113 & \\
\hline
\end{tabular}

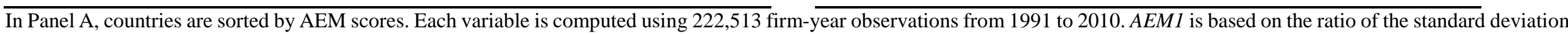

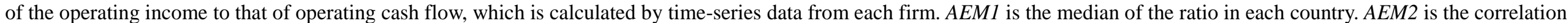

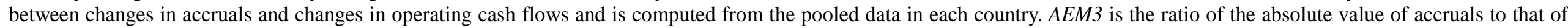
operating cash flows, and is calculated in each firm-year. AEM3 represents each country's median data. The score for $A E M$ is the average rank of $A E M 1$, AEM2, and AEM3.

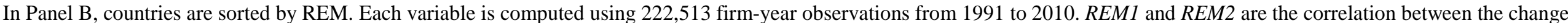

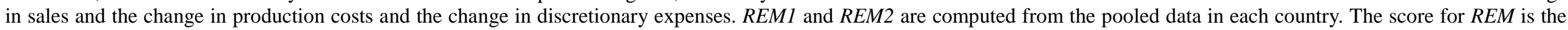
average rank of REM1 and REM2. 
Table 3

Institutional variables in each country.

\begin{tabular}{|c|c|c|c|c|}
\hline Country & $\begin{array}{c}\text { Outside Investor } \\
\text { Rights }\end{array}$ & Legal Enforcement & Disclosure Index & Analyst Following \\
\hline Australia & 4 & 9.51 & 8 & 2.496 \\
\hline Austria & 2 & 9.36 & 2 & 4.647 \\
\hline Belgium & 0 & 9.44 & 8 & 5.650 \\
\hline Canada & 5 & 9.75 & 8 & 2.651 \\
\hline Chile & 5 & 6.52 & 8 & 1.112 \\
\hline Denmark & 2 & 10.00 & 7 & 4.755 \\
\hline Finland & 3 & 10.00 & 6 & 7.590 \\
\hline France & 3 & 8.68 & 10 & 5.665 \\
\hline Germany & 1 & 9.02 & 5 & 5.509 \\
\hline Greece & 2 & 6.82 & 1 & 2.212 \\
\hline Hong Kong & 5 & 8.91 & 10 & 2.230 \\
\hline India & 5 & 5.58 & 7 & 1.967 \\
\hline Indonesia & 2 & 2.88 & 8 & 2.970 \\
\hline Ireland & 4 & 8.36 & 10 & 9.362 \\
\hline Israel & 3 & 7.72 & 7 & 1.482 \\
\hline Italy & 1 & 7.07 & 7 & 5.204 \\
\hline Japan & 4 & 8.24 & 7 & 2.244 \\
\hline Jordan & 1 & 6.16 & 5 & 0.365 \\
\hline Malaysia & 4 & 7.72 & 10 & 2.011 \\
\hline Mexico & 1 & 5.37 & 7 & 4.227 \\
\hline Netherlands & 2 & 10.00 & 4 & 9.692 \\
\hline New Zealand & 4 & 10.00 & 10 & 2.525 \\
\hline Nigeria & 3 & 4.34 & 5 & 0.872 \\
\hline Norway & 4 & 10.00 & 7 & 5.642 \\
\hline Pakistan & 5 & 3.67 & 6 & 1.036 \\
\hline Philippines & 3 & 3.47 & 1 & 1.285 \\
\hline Portugal & 3 & 7.19 & 6 & 5.403 \\
\hline Singapore & 4 & 8.93 & 10 & 1.811 \\
\hline South Africa & 5 & 6.45 & 8 & 3.211 \\
\hline South Korea & 2 & 5.55 & 6 & 2.384 \\
\hline Spain & 4 & 7.14 & 5 & 9.349 \\
\hline Sri Lanka & 3 & 4.66 & 4 & 0.155 \\
\hline Sweden & 3 & 10.00 & 2 & 4.270 \\
\hline Switzerland & 2 & 10.00 & 2 & 7.990 \\
\hline Taiwan & 3 & 7.37 & 6 & 2.200 \\
\hline Thailand & 2 & 4.89 & 10 & 2.730 \\
\hline United Kingdom & 5 & 9.22 & 10 & 6.046 \\
\hline United States & 5 & 9.54 & 7 & 5.209 \\
\hline Mean & 3.13 & 7.62 & 6.58 & 3.846 \\
\hline Median & 3 & 7.98 & 7 & 2.850 \\
\hline Std & 1.40 & 2.14 & 2.64 & 2.571 \\
\hline
\end{tabular}

Outside Investor Rights is anti-director rights, an index aggregating shareholder rights. The anti-director rights index is formed by adding 1 when (1) the country allows shareholders to mail their proxy vote to the firm; (2) shareholders are not required to deposit their shares prior to the general shareholders' meeting; (3) cumulative voting or proportional representation of minorities in the board of directors is allowed; (4) an oppressed minorities mechanism is in place; (5) the minimum percentage of share capital that entitles a shareholder to call for an extraordinary shareholders' meeting is less than or equal to $10 \%$ (the sample median); or (6) shareholders have preemptive rights that can be waived only by a shareholders' vote (La Porta et al., 1998). In our study, the index ranges from 0 to 5. Following Leuz et al. (2003), we compute Legal Enforcement as the average score across three variables used in La Porta et al. (1998): (1) the efficiency of the judicial system, (2) an assessment of rule of law, and (3) the corruption index. All three variables range from 0 to 10. Disclosure Index is obtained from the World Bank website. Analyst Following is the number of analyst following per firm-year in each country. 
Table 4

Correlation between AEM, REM, and institutional variables.

\begin{tabular}{lccccc}
\hline & $\begin{array}{c}\text { Score for } \\
\text { AEM }\end{array}$ & $\begin{array}{c}\text { Score for } \\
\text { REM }\end{array}$ & $\begin{array}{c}\text { Outside } \\
\text { Investor } \\
\text { Rights }\end{array}$ & $\begin{array}{c}\text { Legal } \\
\text { Enforcement }\end{array}$ & $\begin{array}{c}\text { Disclosure } \\
\text { Index }\end{array}$ \\
\hline Score for REM & -0.435 & & & & \\
Outside Investor & $(0.006)$ & -0.428 & 0.465 & & \\
Rights & $(0.007)$ & $(0.003)$ & & & \\
Legal & -0.326 & -0.076 & 0.073 & & \\
Enforcement & $(0.046)$ & $(0.649)$ & $(0.665)$ & & \\
Disclosure & -0.137 & 0.174 & 0.321 & 0.081 & \\
Index & $(0.412)$ & $(0.296)$ & $(0.050)$ & $(0.629)$ & \\
Analyst & -0.032 & -0.411 & -0.164 & 0.525 & -0.048 \\
Following & $(0.851)$ & $(0.010)$ & $(0.325)$ & $(0.001)$ & $(0.774)$ \\
\hline
\end{tabular}

The variables are defined in Tables 2 and $3 ; \mathrm{n}=38$; the $p$-values are in parentheses. 
Table 5

Regression results of earnings management and investor protection.

Panel A: Regression results for AEM

\begin{tabular}{|c|c|c|c|c|c|}
\hline \multirow[b]{2}{*}{ Constant } & \multicolumn{5}{|c|}{ Dependent variable $=A E M$} \\
\hline & $\begin{array}{c}28.434 * * * \\
(8.397)\end{array}$ & $\begin{array}{c}27.014^{* * *} \\
(7.831)\end{array}$ & $\begin{array}{c}23.298 * * * \\
(6.291)\end{array}$ & $\begin{array}{c}20.881 * * * \\
(5.616)\end{array}$ & $\begin{array}{c}34.183^{* * *} \\
(6.896)\end{array}$ \\
\hline Outside Investor Rights & $\begin{array}{c}-0.458 * * * \\
(-3.012)\end{array}$ & & & & $\begin{array}{c}-0.392 * * \\
(-2.412)\end{array}$ \\
\hline Legal Enforcement & & $\begin{array}{c}-0.385 * * \\
(-2.497)\end{array}$ & & & $\begin{array}{c}-0.418 * * \\
(-2.316)\end{array}$ \\
\hline Disclosure Index & & & $\begin{array}{c}-0.195 \\
(-1.172)\end{array}$ & & $\begin{array}{c}-0.049 \\
(-0.319)\end{array}$ \\
\hline Analyst Following & & & & $\begin{array}{c}-0.071 \\
(-0.426)\end{array}$ & $\begin{array}{c}0.106 \\
(0.575)\end{array}$ \\
\hline$R^{2}$ (or Adjusted $R^{2}$ ) & 0.201 & 0.148 & 0.037 & 0.005 & 0.253 \\
\hline Number of Observations & 38 & 38 & 38 & 38 & 38 \\
\hline
\end{tabular}

Panel B: Regression results for REM

\begin{tabular}{|c|c|c|c|c|c|}
\hline \multirow[b]{2}{*}{ Constant } & \multicolumn{5}{|c|}{ Dependent variable $=R E M$} \\
\hline & $\begin{array}{c}10.074 * * * \\
(3.019)\end{array}$ & $\begin{array}{c}20.561 * * * \\
(5.511)\end{array}$ & $\begin{array}{c}16.160 * * * \\
(4.345)\end{array}$ & $\begin{array}{c}27.002 * * * \\
(7.849)\end{array}$ & $\begin{array}{c}15.949 * * * \\
(3.220)\end{array}$ \\
\hline Outside Investor Rights & $\begin{array}{c}0.483 * * * \\
(3.224)\end{array}$ & - & - & - & $\begin{array}{c}0.373 * * \\
(2.298)\end{array}$ \\
\hline Legal Enforcement & - & $\begin{array}{c}-0.054 \\
(-0.326)\end{array}$ & - & - & $\begin{array}{c}0.160 \\
(0.887)\end{array}$ \\
\hline Disclosure Index & - & - & $\begin{array}{c}0.171 \\
(1.026)\end{array}$ & - & $\begin{array}{c}0.065 \\
(0.421)\end{array}$ \\
\hline Analyst Following & - & - & - & $\begin{array}{c}-0.385 * * \\
(-2.502)\end{array}$ & $\begin{array}{c}-0.416^{* *} \\
(-2.262)\end{array}$ \\
\hline$R^{2}$ (or Adjusted $R^{2}$ ) & 0.224 & 0.003 & 0.028 & 0.148 & 0.254 \\
\hline Number of Observations & 38 & 38 & 38 & 38 & 38 \\
\hline
\end{tabular}

The $t$-statistics are in parentheses. ***, **, and * indicate significance at the $1 \%, 5 \%$, and $10 \%$ levels (two-tailed). For equation (11), $R^{2}$ shows the adjusted $R^{2}$. All variables are defined in Tables 2 and 3. 
Table 6

2SLS results of earnings management and investor protection.

\begin{tabular}{lcc}
\hline & $A E M$ & $R E M$ \\
\hline Constant & $43.725^{* * *}$ & 7.847 \\
Outside Investor Rights & $(6.114)$ & $(1.128)$ \\
& $-1.050^{* * *}$ & $0.974 * * *$ \\
Legal Enforcement & $(-2.877)$ & $(2.741)$ \\
& -0.247 & -0.071 \\
Disclosure Index & $(-0.947)$ & $(-0.281)$ \\
& 0.180 & -0.143 \\
Analyst Following & $(0.863)$ & $(-0.706)$ \\
& -0.125 & -0.162 \\
Adjusted $R^{2}$ & $(-0.489)$ & $(-0.652)$ \\
Number of Observations & -0.119 & -0.060 \\
\end{tabular}

The $t$-statistics are in parentheses. ${ }^{* * *},{ }^{* *}$, and $*$ indicate significance at the $1 \%, 5 \%$, and $10 \%$ levels (two-tailed). The regressions are estimated using two-stage least squares (2SLS). Legal origin and GDP ranks are employed as instrumental variables for outside investor rights and legal enforcement. Following Leuz et al. (2003), English, French, German, and Scandinavian legal origins based on the classifications from La Porta et al. (1998) are transformed into three dummy variables. GDP is computed as average per capita GDP from 1981 to 1990 in each country. The other variables are defined in Tables 2 and 3. 
Table 7

Regression results of earnings management and investor protection: Controlling for Big 4 audits ratio.

\begin{tabular}{lcc}
\hline & $A E M$ & $R E M$ \\
\hline Constant & $29.134^{* * *}$ & $14.771^{* * *}$ \\
Outside Investor Rights & $(6.461)$ & $(3.203)$ \\
& $-0.438^{* *}$ & $0.371^{*}$ \\
Legal Enforcement & $(-2.337)$ & $(1.934)$ \\
& $-0.336^{*}$ & 0.132 \\
Disclosure Index & $(-1.831)$ & $(0.703)$ \\
& 0.011 & 0.048 \\
Analyst Following & $(0.068)$ & $(0.285)$ \\
& 0.177 & $-0.466 * *$ \\
Big4 Ratio & $(1.013)$ & $(-2.603)$ \\
Adjusted $R^{2}$ & -0.128 & 0.046 \\
Number of Observations & $-0.721)$ & $(0.254)$ \\
\end{tabular}

The $t$-statistics are in parentheses. ${ }^{* * *}, * *$, and * indicate significance at the $1 \%, 5 \%$, and $10 \%$ levels (two-tailed). Big4 Ratio is the ratio of firms audited by the Big 4 in each country. The other variables are defined in Tables 2 and 3. 


\section{Table 8}

Regression results of REM and investor protection: using REM_Roy based on Roychowdhury (2006) model.

\begin{tabular}{lc}
\hline & REM_Roy \\
\hline Constant & 1.574 \\
Outside Investor Rights & $(0.352)$ \\
& $0.269 *$ \\
Legal Enforcement & $(1.782)$ \\
& $0.573^{* * *}$ \\
Disclosure Index & $(3.365)$ \\
& 0.053 \\
Analyst Following & $(0.369)$ \\
& 0.021 \\
Adjusted $R^{2}$ & $(0.121)$ \\
Number of Observations & 0.374 \\
\hline
\end{tabular}

The $t$-statistics are in parentheses. ***, **, and * indicate significance at the $1 \%, 5 \%$, and $10 \%$ levels (two-tailed). The dependent variable, REM_Roy, is calculated as follows. To obtain the abnormal level of production costs (A_Prod) and discretionary expenses ( $\left.A \_D E\right)$, our estimation uses the following regression models. Regression models are estimated for each industry-year combination in each country, where industry is identified by a two-digit SIC code:

$\operatorname{Prod}_{i j t} /$ Asset $_{i j t-1}=\beta_{0}+\beta_{1}\left(1 /\right.$ Asset $\left._{i j t-1}\right)+\beta_{2}\left(\right.$ Sales $_{i j t} /$ Asset $\left._{i j t-1}\right)+\beta_{3}\left(\Delta\right.$ Sales $_{i j t} /$ Asset $\left._{i j t-1}\right)$

$$
+\beta_{4}\left(\Delta \text { Salesijt-1 }^{\prime} \text { Assetijt-1 }\right)+\varepsilon i j t
$$

$D E_{i j t} /$ Asset $_{i j t-1}=\beta_{0}+\beta_{1}\left(1 /\right.$ Asset $\left._{i j t-1}\right)+\beta_{2}\left(\right.$ Sales $_{i j t-1} /$ Asset $\left._{i j t-1}\right)+\varepsilon_{i j t}$

Standard deviations of $A \_P r o d$ and $A \_D E$ are computed from the pooled sample from each country $\left(\sigma\left(A \_P r o d\right)\right.$ and $\left.\sigma\left(A \_D E\right)\right)$ and used as the country-level representative value. The aggregated REM score (REM_Roy) is computed as the average rank of $\sigma\left(A \_P r o d\right)$ and $\sigma\left(A \_D E\right)$. Other variables are defined in Tables 2 and 3. 
Table 9

Regression results of earnings management and investor protection: Another proxy for Legal Enforcement.

\begin{tabular}{|c|c|c|}
\hline & $A E M$ & $R E M$ \\
\hline \multirow[t]{2}{*}{ Constant } & $34.483 * * *$ & $16.291 * * *$ \\
\hline & $(6.843)$ & (3.235) \\
\hline \multirow[t]{2}{*}{ Outside Investor Rights } & $-0.390 * *$ & $0.391 * *$ \\
\hline & $(-2.372)$ & $(2.375)$ \\
\hline \multirow[t]{2}{*}{ Legal Enforcement } & $-0.375^{* *}$ & 0.065 \\
\hline & $(-2.156)$ & $(0.376)$ \\
\hline \multirow[t]{2}{*}{ Disclosure Index } & -0.064 & 0.062 \\
\hline & $(-0.405)$ & $(0.396)$ \\
\hline \multirow[t]{2}{*}{ Analyst Following } & 0.061 & $-0.354^{*}$ \\
\hline & $(0.343)$ & $(-1.992)$ \\
\hline Adjusted $R^{2}$ & 0.239 & 0.240 \\
\hline Number of Observations & 38 & 38 \\
\hline
\end{tabular}

The $t$-statistics are in parentheses. ${ }^{* * *},{ }^{* *}$, and * indicate significance at the $1 \%, 5 \%$, and $10 \%$ levels (two-tailed). Legal Enforcement is the average score across three legal variables: (1) the efficiency of the judicial system, as used in La Porta et al. (1998); (2) an assessment of rule of law, based on Kaufmann et al. (2004); and (3) the corruption index, based on Kaufmann et al. (2004). The first variables range from 0 to 10 and the second and third from -2.5 to +2.5 . The other variables are defined in Table 2 and Table 3. 


\section{Table 10}

Regression results of earnings management and investor protection based on country-year earnings management measures.

\begin{tabular}{lcc}
\hline & $A E M$ & $R E M$ \\
\hline Constant & $42.915^{* * *}$ & $7.510^{* *}$ \\
& $(14.137)$ & $(2.174)$ \\
Outside Investor Rights & $-0.369^{* * *}$ & $0.154^{* * *}$ \\
& $(-9.310)$ & $(3.420)$ \\
Legal Enforcement & $-0.348^{* * *}$ & $0.087^{*}$ \\
& $(-7.829)$ & $(1.719)$ \\
Disclosure Index & -0.054 & $0.131^{* * *}$ \\
& $(-1.426)$ & $(3.044)$ \\
Analyst Following & -0.035 & $-0.153^{* * *}$ \\
Year_Dummy & $(-0.758)$ & $(-2.922)$ \\
Adjusted $R^{2}$ & included & Included \\
Number of Observations & & 0.164 \\
\hline
\end{tabular}

The $t$-statistics are in parentheses. ***, **, and * indicate significance at the 1\%, 5\%, and 10\% levels (two-tailed). All variables are defined in Tables 2 and 3. 